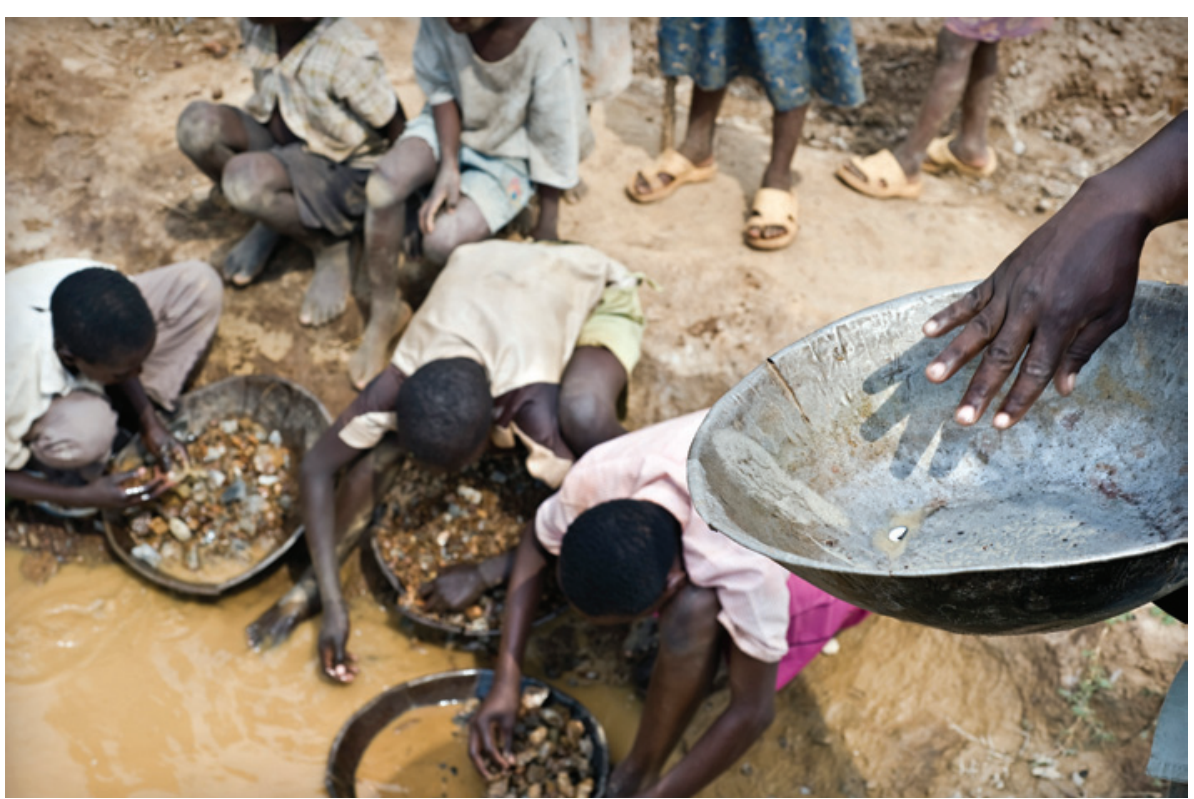

Small-scale gold mining is a growing source of toxic mercury emissions.

\title{
ENVIRONMENT
}

\section{Tough talk over mercury treaty}

\section{Nations debate how to share the costs of cutting emissions.}

\section{BY JANE QIU}

G overnments are on the verge of agreeing the first legally binding, global treaty to tackle mercury pollution. It aims to clean up the legacy of centuries of untrammelled emissions of the toxic metal, and to limit future contamination from sources as diverse as coal-fired power plants and gold mining.

Delegates from 128 countries are expected to meet next week in Geneva, Switzerland, for a fifth and final round of treaty negotiations. All agree that action is needed urgently to reduce mercury emissions, which pose risks to the environment and human health. But consensus on how to achieve that will not come easily. The current top emitters, in Asia, want to know why they should shoulder the burden of clean-up when much of the world's mercury pollution is due to the past economic growth of developed nations - an argument that parallels one of the main stumbling blocks to an international greenhouse-gas agreement.

Yet with mercury able to drift freely through air, soil, rivers and oceans, it is crucial that the negotiations deliver "a global treaty that is going to be implementable in all the countries", says Fernando Lugris, chairman of the Intergovernmental Negotiating Committee of the United Nations Environment Programme (UNEP), which is coordinating the treaty.

According to a draft version of UNEP's 2013 Global Mercury Report, about 6,500 tonnes of mercury was emitted into the air in 2010. Roughly $30 \%$ came from human activities, and a further $15 \%$ from natural sources such as volcanoes and erosion. The remainder was from the re-emission from soils, water and vegetation of mercury released into the environment decades ago. "Once emitted into the air, it's like a genie that has escaped the bottle," says David Streets, an environmental scientist at Argonne National Laboratory in Illinois. "It takes decades or even centuries to get it fixed."

The UNEP report points out that mercury concentrations in the upper 100 metres of the oceans have doubled in the past century; top marine predators in the Arctic Ocean contain up to 12 times more mercury than in preindustrial times, and contaminated seafood is a significant source of human exposure. The World Health Organization (WHO) rates mercury as one of the top ten chemicals of major public health concern - it can damage the brain and is a particular hazard for fetuses.

Streets estimates that human activity has released a grand total of about 350,000 tonnes of mercury, with roughly $40 \%$ of those emissions occurring before 1850 (see 'Quicksilver quantified'). Much of the rest came from silver and gold mining in the late nineteenth century, when mercury was used to extract precious metals. However, emissions have soared in recent decades, propelled by small-scale, or artisanal, gold mining in Africa and Latin America, and rapid industrialization in Asia (D. G. Streets et al. Environ. Sci. Technol. 45, 10485-10491; 2011). China is now the biggest emitter, contributing $30 \%$ of global anthropogenic emissions.

Cleaning up industrial processes, for example by capturing mercury released from burning coal, involves costly technology. In the negotiations, "the biggest contention is who

\section{QUICKSILVER QUANTIFIED}

Anthropogenic mercury emissions are rising in Asia, but pollution more than a century old persists globally, raising questions about who should pay to clean up the metal.

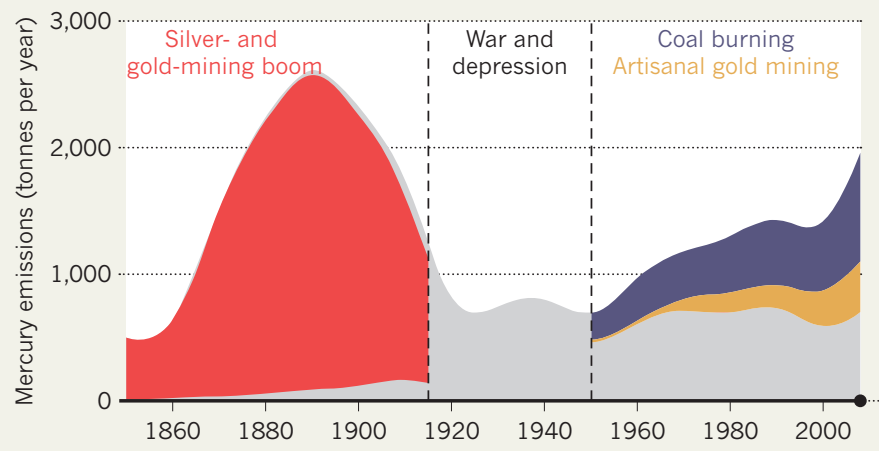

Percentage by sector: 2010 Coal burning Other mining and smelting 7 Consumer waste

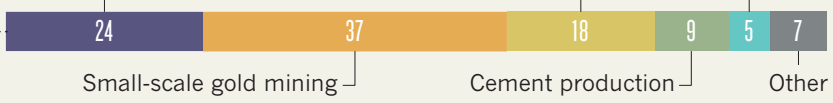

Percentage by location: 2010

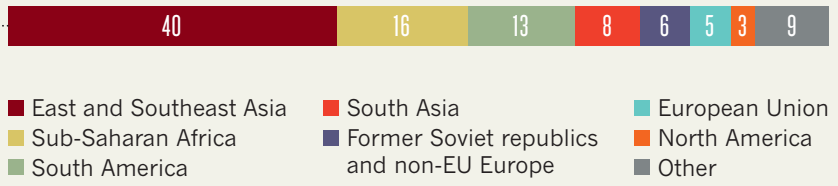


should pay", says Ludovic Bernaudat, a mercury expert at the United Nations Industrial Development Organization in Vienna. "There are a lot of tensions right now."

Before the latest round of negotiations, in June 2012, the discussions aimed at an agreement for all countries to cap mercury emissions. But developing nations such as China and India - second only to China as an emitter - were adamant that this would be unfair unless developed nations helped with the cost and technologies. Common measures for controlling air pollution have the potential to reduce mercury emissions from coal plants by about $36 \%$, "but to go further you'd need specific mercury-control technologies that can remove $90 \%$ of emissions, which are only available in developed countries", says Wang Shuxiao, an environment scientist at Tsinghua University in Beijing, who is part of the Chinese delegation.

Developed nations seem unlikely to commit to funding the transfer of such technologies. Negotiators may settle on an agreement that requires countries to set national targets that they can meet with the best mercurycontrol measures available to them, and to beef up monitoring programmes. UNEP predicts that such measures could reduce emissions in industrial regions by $25 \%$ by 2020 , compared with an increase of up to $25 \%$ under a business-as-usual scenario.

The treaty also aims to limit emissions from artisanal gold mining, which is largely unregulated. Miners soak crushed ore in mercury to form an amalgam that leaves impurities behind; heating the amalgam frees the gold, but releases mercury into the air. "Most of them are unaware of the health hazards of mercury vapour and nobody wears a mask," says Nicola Pirrone, director of the Institute of Atmospheric Pollution Research in Rome. The treaty is likely to recommend that countries register and monitor mining, and will encourage technologies that capture mercury vapour or use jets of water and air to separate gold from ores (see Nature 486, 306-307; 2012).

In late February, at the Global Ministerial Environment Forum in Nairobi, UNEP's governing council will debate the draft treaty that will emerge from next week's meeting. UNEP expects countries to ratify the treaty later this year. Even if the treaty does not set binding caps, "it should still build enough momentum for countries to commit to serious efforts to tackle the problem", says John Munthe, an environment-policy researcher at the Swedish Environmental Research Institute in Stockholm. $\rightarrow$ NATURE.COM Read more about pollution caused by gold mining: go.nature.com/wlarqr
"There are plenty of low-hanging fruits that could make a big difference in reducing global mercury emissions." -

REGENERATIVE MEDICINE

Safety of induced
stem cells gets a boost

Fears of immune response have been overestimated.

\section{BY MONYA BAKER}

A paper published in Nature today ${ }^{1}$ could dispel a cloud over the hopes of turning a patient's own cells into perfectly matched replacement tissues.

Scientists first reported in 2007 that a person's cells could be reprogrammed to an embryo-like state, and so could form any type of cell in the body. Medical researchers immediately imagined using these induced pluripotent stem (iPS) cells' to create an endless supply of genetically matched replacement tissues to treat a range of diseases: fresh pancreatic tissue for diabetics, for example, or new nerve cells for people with Parkinson's.

The strategy also seemed to offer a way around the ethical complexities of using stem cells derived from human embryos. But then came the worries about possible side effects. Particularly bad news came from a 2011 study $^{2}$ showing that iPS cells provoked immune responses when injected into the mice from which they had been derived, casting doubt over one of the key advantages of the cells.

The latest Nature study ${ }^{1}$ rejects that conclusion. Masumi Abe, a geneticist at the National Institute of Radiological Sciences in Chiba, Japan, and his team took iPS cells derived from mice and injected them back into the animals. For comparison, they injected other mice with embryonic stem (ES) cells. Yet unlike the 2011 study, which saw iPS cells perform worse than ES cells, the team found no differences between the immune responses of each group. The researchers also transplanted skin and bonemarrow cells derived from iPS or ES cells into mice and achieved similar success rates between the groups. The immune response of both sets of tissues is "indistinguishable", says Abe.

Konrad Hochedlinger, a stem-cell scientist at Massachusetts General Hospital in Boston, says that the result will probably "calm people down" about iPS cells. "It is definitely reassuring," he says.

The findings follow another positive study on iPS cells, published late last year ${ }^{3}$, which found that the reprogramming process causes fewer mutations than previously thought. Flora Vaccarino, a neuroscientist at Yale University in New Haven, Connecticut, and her colleagues used high-resolution DNA analysis to compare the genomes of iPS cells and the adult cells from which they were derived. They

found that most of the DNA mutations in the iPS cells did not arise during reprogramming but had been present in the parent cells.

Yang Xu, a stem-cell scientist at the University of California, San Diego, and co-author of the 2011 study $^{2}$, says that the new work does not dispel all concerns about the immune response provoked by iPS cells.

$\mathrm{Xu}$ points out that the skin and bone-marrow cells used in the latest study were not grown from iPS cells in culture, as they would be for clinical use. Instead, the researchers mixed iPS cells into early mouse embryos to make 'chimaeric' embryos. They then used skin and bonemarrow tissues that arose from iPS cells after

"The result will probably calm people down. It is definitely reassuring." as the mice developed, which would explain why Abe and his colleagues observed a limited immune response. Transplanting tissues from chimaeric mice is "flawed", he says.

Producing chimaeric embryos is a standard technique for testing whether mouse iPS cells have been fully reprogrammed, says Jakub Tolar, a clinician at the University of Minnesota in Minneapolis, but he notes that differentiating cells in culture outside the body is much harder. Tolar, who hopes to use iPS cells to treat the childhood skin disease epidermolysis bullosa, adds that iPS-cell therapies will use human cells, which could behave quite differently from mouse cells. "It's helpful that they've done this, but it is absolutely different when you go to something that is cultured," he says.

Hochedlinger believes that iPS cells are just as promising for cell transplantation as ES cells, although many issues stand between the lab and the clinic. The differences between the two kinds of stem cell are minor compared with the differences in how individual cell lines grow and differentiate in culture, he says.

"Based on what we know at this time from mice," he says, "iPS cells are as good as ES cells, and should be as safe."

\footnotetext{
1. Araki, R. et al. Nature http://dx.doi.org/10.1038/ nature11807 (2013).

2. Zhao, T., Zhang, Z.-N., Rong, Z. \& Xu, Y. Nature 474 , 212-215 (2011).

3. Abyzov, A. et al. Nature 492, 438-442 (2012).
} 